\title{
ROUTE OPTIMIZATION FOR SOLID WASTE COLLECTION: TRABZON (TURKEY) CASE STUDY
}

\section{O. APAYDIN* \\ M. T. GONULLU}

\author{
Yildiz Technical University \\ Environmental Engineering Department \\ 34349 Besiktas, Istanbul, Turkey
}

Received: 20/12/05

Accepted: 29/03/06 *to whom all correspondence should be addressed: e-mail: apaydin@yildiz.edu.tr

\begin{abstract}
In a municipal solid waste management system, decreasing collection/hauling costs, which consist of $85 \%$ of total disposal expenditure, can be carried out by a route optimization. Thus, a huge amount of economical benefits is getting furnished. If route optimization is performed in solid waste collection/hauling process, due to reductions in "empty miles" negativity, total expenditures will be decreased.

Trabzon City located in the northeast side of Turkey has about 185 thousand inhabitants according to Census 2000. The city shares just about $1 \%$ of the Gross Domestic Income in Turkey. In other words, that means that Trabzon City livings have moderate revenue.

The objectives of this study are to optimize for the route of collection/hauling in Trabzon City by taking consideration of data about road net, demographics and solid waste production.

In order to analyse the solid waste collection/hauling process in the city, the processes were recorded by a Sony DCR-TRV145E brand video camera. To use route optimization process, data related in present spending, truck type and capacity, solid waste production, number of inhabitants and Global Positioning System (GPS) receiver data for each route were collected and all the data were analyzed with each other.

For 39 districts in the city, a shortest path model was used in order to optimize solid waste collection/hauling processes, as minimum cost was aimed. The Route View Pro ${ }^{\mathrm{TM}}$ software as an optimization tool was used for that purpose. Geographic Information System (GIS) elements such as numerical pathways, demographic distribution, container distribution and solid waste production amount were integrated to the software. To give an idea, thematic container layer has 777 container location points for the entire city.

After performing routes by the software, the optimized routes were compared with the present routes. Success by the optimization process was around 4-59 \% for distance and 14-65 \% for time. Consequently, a route optimization process on the street stationary container collection system will contribute a benefit by $24 \%$ in total cost.
\end{abstract}

KEYWORDS: GIS, Trabzon City, route optimization, solid waste, collection/hauling.

\section{INTRODUCTION}

Municipal solid waste collection (MSWC) has about $85 \%$ proportion of the total cost for solid waste management system [1]. MSWC is the beginning of the process of solid waste management which consists of generation, collection, transfer, treatment and final disposal. Integrated solid waste management involves a variety of programs and facilities, and incorporates source reduction, reuse, recycling, composting, incineration and landfilling. Waste stream from a city to any destination is charged a unit hauls cost based on per-ton distance. However, waste stream of rejects from a processing facility to conversion or disposal facility is ignored, because it has no significant effect. Typical haul costs are in the range from 0.07 to 0.21 US $\$ \mathrm{~km}^{-1}$ ton $^{-1}$ for collection vehicles, while transporting waste by transfer trailers reduces costs to 0.03 to $0.10 \mathrm{US} \$ \mathrm{~km}^{-1}$ ton $^{-1}$ [2]. Population of Turkey is $67,844,903$ according to Census 2000 [3]. Turkey takes place in the group of medium income 
level. There are 3215 municipalities in Turkey. Only 11 municipalities had a sanitary landfill in 2000. $12 \%$ of the total population of Turkey lives in cities located in Black Sea Region. Trabzon City is one of cities in the region. In the region, Sanitary Landfill does not exist. It is determined that MSWC unit cost is between 0.04-0.06 US\$ $\mathrm{km}^{-1}$ ton $^{-1}$ and haul cost is between 0.02-0.04 US\$ $\mathrm{km}^{-1}$ ton $^{-1}$ [4]. Annual income of inhabitants living in Trabzon City is US\$6100 (min: 1800, mean: 6100, max: 42000) [5]. A study for Istanbul emphasizes that yearly collection expenses of solid waste can be reduced about $50 \%$ when an optimization effort is used [6]. According to another study, for developing countries, ratio of total collection costs was determined to be approximately $79 \%$ for low income, $74-79 \%$ for middle income and $55-70 \%$ for high income [7]. Cost, of course, is proportional to distance. Conventional dispatching methods have generally focused on minimizing. Decision support system approach, a dispatching problem, has a focus on empty miles minimization [8]. Studies performed in a small district of Trabzon city, by route optimization, pointed out a success of $22 \%$ reduction for collection time and $20 \%$ reduction for collection distance for the MSW collection processes $[9,10]$. It is necessary that empty miles minimization is performed on MSW collection/hauling processes.

Present paper's objectives are:

1. To create MSWC data recorded by a video camera by riding in collection vehicle cabined.

2. To use data gathered by observing the collection of MSWC in 39 districts in the city and to form a GIS database on the route map of Trabzon

3. To compare present route with optimized route for cost and time

\section{SOLID WASTE MANAGEMENT IN TRABZON CITY}

To collect wastes, Trabzon municipality has located about 2,800 stationary containers in different sizes $(150,300$, and $400 \mathrm{~L})$ in the residential area. Wastes from households are dropped into these containers by inhabitants. Waste containers are unloaded at least twice a week by 20 trucks that have a total capacity of $154 \mathrm{~m} 3$. Total length of road network is about $416 \mathrm{~km}$ and collection vehicles travel $60 \%$ of that distance each day. On the other hand, collection through some central busy streets such as Maras Caddesi is performed 7 or 8 times a day. The number of total daily tour reaches at 50 for MSWC process in the city. MSWC facility is subjected for 6 days a week. The city has no transfer station, yet. Collected garbage is dumped at the seaside of Black Sea by being blended with demolition waste and soil in a ratio of about $50 \%$. The dumping area with $2 \mathrm{Ha}$ has been prepared as surrounded by breakwater walls in the sea [4]. Annual income of inhabitants living in Trabzon City is 6100 US\$ (min: 1800, mean: 6100, max: 42000) [5].

To begin understanding collection process in the city, some daily operational data was determined for collection vehicles and presented in Table 1 and Table 2.

Table 1. Route number and total collected MSW subjected for each truck per day

\begin{tabular}{lcc}
$\begin{array}{l}\text { Vehicle registration } \\
\text { plate ID }\end{array}$ & $\begin{array}{c}\text { Vehicle route number, } \\
\text { route } \mathrm{d}^{-1}\end{array}$ & $\begin{array}{c}\text { Total MSW amount } \\
\text { collected, kg d }^{-1}\end{array}$ \\
\hline 61 DE 762 & 4.17 & 11571 \\
61 DE 761 & 3.67 & 9630 \\
61 DE 772 & 3.67 & 9736 \\
61 DE 773 & 3.67 & 7417 \\
61 DE 775 & 3.67 & 9615 \\
61 DE 766 & 3.5 & 8354 \\
61 DE 771 & 2.5 & 7295 \\
61 DE 763 & 3.67 & 11171 \\
61 DU 367 & 4 & 9576 \\
61 AE 398 & 3 & 6456 \\
\hline Total & 35.5 & 90823 \\
Mean & 3.56 & 9082.3 \\
Standard deviation & 0.48 & 1673.7 \\
\hline
\end{tabular}


Table 2. Densities of MSW collected in trucks in work days

\begin{tabular}{|c|c|c|}
\hline \multirow{2}{*}{ Work days } & \multicolumn{2}{|c|}{$\begin{array}{l}\text { MSW density in collection truck } \\
\mathrm{kg} \mathrm{m}^{-3}\end{array}$} \\
\hline & Mean & $\begin{array}{l}\text { Standard } \\
\text { deviation }\end{array}$ \\
\hline Friday $\left(1^{\text {st }}\right.$ Week $)$ & 343 & 114 \\
\hline Saturday & 377 & 163 \\
\hline Monday & 387 & 94 \\
\hline Tuesday & 357 & 106 \\
\hline Wednesday & 392 & 106 \\
\hline Thursday & 344 & 119 \\
\hline Friday ( $2^{\text {nd }}$ Week) & 385 & 101 \\
\hline Mean & 369 & 115 \\
\hline Standard deviation & 21 & 23 \\
\hline
\end{tabular}

\section{MATERIAL AND METHOD}

In this study, a video camera, Sony DCR-TRV145E, was used in order to analyse solid waste collection/hauling process. By this way, more realistic solid waste collection/hauling costs were produced based on data obtained from records. All data were stored in a GIS database. Projection of digitizing map used in this study has been adjusted Turkish Coordinate System ((GK 3 Degree k=1-ED50 and Category Members: GK Central Meridian 39 (ED50)). The map was containing several layers related in 39 districts. A shortest path model was used in order to optimize solid waste collection/hauling processes, by aiming at minimum distance. The Route View Pro ${ }^{\mathrm{TM}}$ software integrated with GIS elements such as numerical pathways, demographic distribution, container distribution and solid waste production was used as an optimization tool.

\subsection{Determining capacities of containers and vehicles}

\section{Container number $\left(n_{K}\right)$ is computed as follows}

$\mathrm{n}_{\mathrm{K}}=\frac{\mathrm{p}}{\mathrm{P}_{\mathrm{K}}}$,

where $p$ is population living in the area and $P_{K}$ is population for a container. $P_{K}$ is written as $\mathrm{P}_{\mathrm{K}}=\frac{\mathrm{V}_{\mathrm{K}}}{\mathrm{V}_{\mathrm{RP}}}$

where $V_{K}$ is the volume of a container $\left(\mathrm{m}^{3}\right)$ and $V_{\mathrm{RP}}$ is the volume of MSW per person $\left(\mathrm{m}^{3}\right)$. $V_{R P}$ is found this way:

$\mathrm{V}_{\mathrm{RP}}=\frac{\mathrm{V}_{\mathrm{R}}}{\mathrm{P}_{\mathrm{R}}}$ or $\mathrm{V}_{\mathrm{RP}}=\frac{\mathrm{M}}{\mathrm{W}_{\mathrm{p}}}$,

$V_{R}$ is the volume of MSW per residence $\left(\mathrm{m}^{3}\right)\left(V_{R}=4.1 V_{R P}\right), P_{R}$ is the number of people per residence, $M$ is MSW amount per person a day (kg/person.day), $W_{p}$ is unit volume per $\mathrm{kg}$ of MSW in a container. MSW container number to be collected by a vehicle $\left(n_{K}^{\prime}\right)$ is presented as follows

$$
\mathrm{n}_{\mathrm{K}}^{\prime}=\frac{\mathrm{V}_{\mathrm{v}}}{\mathrm{V}_{\mathrm{K}}} \alpha
$$

where $\mathrm{V}_{\mathrm{v}}$ is volume of a vehicle $\left(\mathrm{m}^{3}\right)$ and $\alpha$ is vehicle compaction factor.

The map performed in this study is presented in Figure 1. There are a lot of data having been presented in the figure. Those are:

- Population of study area (Trabzon Municipality is located in The Eastern Black Sea Region of Turkey) is 223976

- The number of districts that exist in Trabzon Municipality are 39

- Total area of the study area is $28689576 \mathrm{~m}^{2}$

- Total road distance traveled by collection vehicle is $416174 \mathrm{~m}$

- The Number of residences living in Trabzon Municipality is 58909 
- Total number of containers used this study are 777 (the volume of each container is $0.8 \mathrm{~m}^{3}$ )

- Temporarily solid waste disposal area is located in the north of Trabzon City)

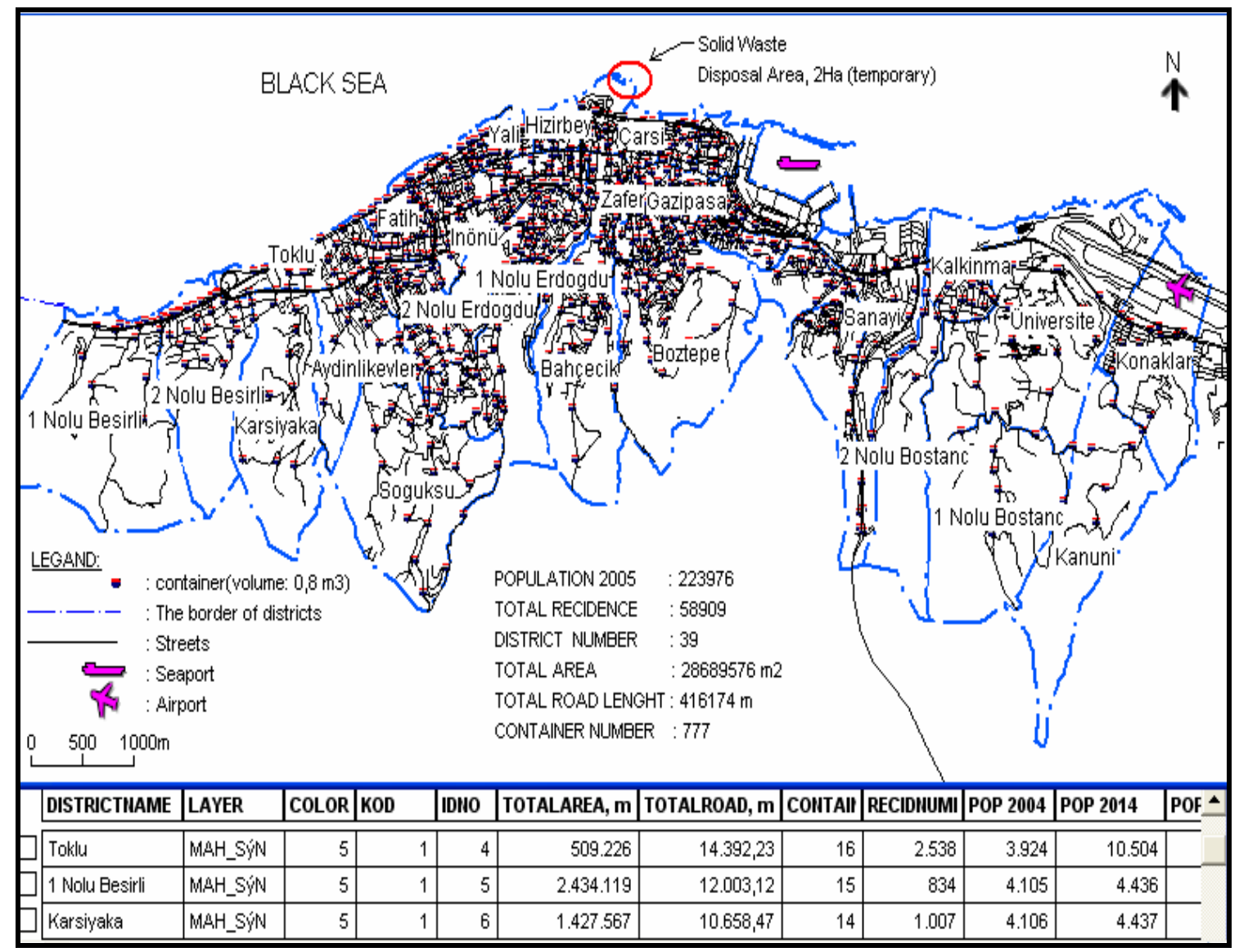

Figure 1. The map of Trabzon City

\section{RESULTS}

Routes optimized by using the software were compared with present routes. The comparison results are presented in Table 3. According to the Table, if the optimized routes are used in solid waste collection system, both distance and time will be decreased by 4-59 \% and 14-65 $\%$, respectively.

After route optimization in the city, optimized total route numbers and total collection and hauling travel distances for truck type/types per day obtained by using present vehicles and containers are given in Table 4. Moreover, Table 5 presents optimized collection and hauling costs obtained from data for possible usage of truck type/types. Total distance and costs of collection/hauling for optimized case of present infrastructure are determined to be $366 \mathrm{~km}$ and US $\$ 1844$ per day. Monthly costs for optimized and present route are US\$55320 and US\$73334, respectively. This difference expresses a decrease by $24.7 \%$ in cost. Table 6 illustrates a cost comparison matrix obtained by binary comparisons of vehicle types. From Table 6 , it is seen that truck in $15 \mathrm{~m}^{3}$ will be the most economical capacity to collect all containers in the city.

\section{CONCLUSIONS}

In solid waste management system, collection of solid waste is the most important process for total disposal costs. In order to decrease total solid waste disposal costs It is necessary to performed route optimization on current solid waste collection paths. This optimization study supported data by video camera from field puts forward that the optimization process supplies successes $24.7 \%$ in distance and $44.3 \%$ in time for collection and hauling. Accordingly, $24.7 \%$ benefit in total expenditure will be acquired. Furthermore, some extra benefits such as 
exhaust and noise emissions, traffic jam, resource saving, etc., which are possibly more important for city life quality than cost, will be acquired by the route optimization

Table 3. Time and distance comparisons for present and optimized cases of routes

\begin{tabular}{ccccccc}
\hline MSW & \multicolumn{2}{c}{ Present routes } & \multicolumn{2}{c}{ Optimized routes } & \multicolumn{2}{c}{ Advantage, \% } \\
\cline { 2 - 7 } $\begin{array}{c}\text { collection } \\
\text { route name }\end{array}$ & $\begin{array}{c}\text { Route } \\
\text { distance, } \mathrm{m}\end{array}$ & $\begin{array}{c}\text { Route } \\
\text { time, s }\end{array}$ & $\begin{array}{c}\text { Route } \\
\text { distance, } \mathrm{m}\end{array}$ & $\begin{array}{c}\text { Route } \\
\text { time, s }\end{array}$ & Distance & Time \\
\hline Route 1 & 4833 & 2150 & 1966 & 702 & 59 & 67 \\
Route 2 & 2590 & 1498 & 1481 & 529 & 43 & 65 \\
Route 3 & 2997 & 998 & 2574 & 859 & 14 & 14 \\
Route 4 & 6930 & 4016 & 6149 & 2202 & 11 & 45 \\
Route 5 & 2621 & 1477 & 2523 & 900 & 4 & 39 \\
Route 6 & 2751 & 1580 & 2015 & 668 & 27 & 58 \\
Route 7 & 3337 & 1491 & 3090 & 1104 & 7 & 26 \\
Route 8 & 3034 & 1760 & 1801 & 644 & 41 & 63 \\
Route 9 & 5577 & 2148 & 4696 & 1682 & 16 & 22 \\
\hline Mean & 3852,2 & 1902 & 2921,7 & 1032,2 & 24,7 & 44,3 \\
\hline
\end{tabular}

Table 4. Optimized route numbers and travel distances for truck types

\begin{tabular}{|c|c|c|c|c|c|}
\hline \multirow{2}{*}{ Vehicle capacity } & \multirow{2}{*}{$\begin{array}{c}\text { Total } \\
\text { container } \\
\text { number, } n_{\mathrm{K}}\end{array}$} & \multirow{2}{*}{$\begin{array}{c}\text { Container } \\
\text { number per } \\
\text { vehicle } \\
(\alpha=2), n_{\mathrm{K}}^{\prime}\end{array}$} & \multirow{2}{*}{$\begin{array}{l}\text { Vehicle } \\
\text { route } \\
\text { number } \\
\text { per day }\end{array}$} & \multicolumn{2}{|c|}{$\begin{array}{c}\text { Vehicle travel distance } \\
\text { per day, km }\end{array}$} \\
\hline & & & & collection & hauling \\
\hline $7 \mathrm{~m}^{3}$ & 777 & 17 & 46 & 138 & 276 \\
\hline $12 \mathrm{~m}^{3}$ & 777 & 27 & 29 & 145 & 174 \\
\hline $15 \mathrm{~m}^{3}$ & 777 & 37 & 21 & 147 & 126 \\
\hline All of the vehicles & 777 & - & 36 & 150 & 216 \\
\hline
\end{tabular}

Table 5. Costs developed for optimized collection/hauling as depending on truck types Costs, US\$ day ${ }^{-1}$

\begin{tabular}{cccc}
\cline { 2 - 4 } Vehicle capacity & $\begin{array}{c}\text { collection } \\
\left(0.05 \cup S \$ \mathrm{~km}^{-1} \text { ton }^{-1}\right)\end{array}$ & $\begin{array}{c}\text { hauling } \\
\left(0.02 \cup S \$ \mathrm{~km}^{-1} \text { ton }^{-1}\right)\end{array}$ & Total \\
\hline $7 \mathrm{~m}^{3}$ & 1077 & 861 & 1938 \\
$12 \mathrm{~m}^{3}$ & 1131 & 543 & 1674 \\
$15 \mathrm{~m}^{3}$ & 1147 & 394 & 1541 \\
All of the vehicles & 1170 & 674 & 1844 \\
\hline
\end{tabular}

Table 6. A matrix developed by binary comparison of vehicle collection costs

\begin{tabular}{ccccc}
\hline $\begin{array}{c}\text { \% Benefit }= \\
(\text { Column/Line) } * 100\end{array}$ & $7 \mathrm{~m}^{3}$ & $12 \mathrm{~m}^{3}$ & $15 \mathrm{~m}^{3}$ & $\begin{array}{c}\text { All of the } \\
\text { vehicles }\end{array}$ \\
\hline $7 \mathrm{~m}^{3}$ & 0.0 & 15,7 & 25,7 & 5,1 \\
$12 \mathrm{~m}^{3}$ & $-15,7$ & 0.0 & 8,6 & $-10,1$ \\
$15 \mathrm{~m}^{3}$ & $-25,7$ & $-8,6$ & 0.0 & $-19,6$ \\
All of the vehicles & $-5,1$ & 10,1 & 19,6 & 0.0 \\
\hline
\end{tabular}




\section{ACKNOWLEDGEMENTS}

The authors thank the Basarsoft for their assistance in the software used in this study. Furthermore, they thank the Municipality of Trabzon. This research was supported by Yildiz

Technical University Scientific Projects Coordination Department. Project Number: 25/05/02.02.

\section{REFERENCES}

1. Ludwig H.F. and Black R.J. (1968) Report on the solid waste problem. Journal of Sanitary Engineering Div., 94(2), 355-370.

2. Modak A., Everett J.S. (1996) Optimal regional scheduling of solid waste system. II: Model solution, ASCE Journal of Environmental Engineering, 122(9), 793-799.

3. SIS (2002) Population Censuses, year 2000: City 61-Trabzon, ISBN 975-19-3065.

4. Apaydin, O., Geographical information system (GIS) supported optimization of solid waste management alternatives in Trabzon City, Ph.D. Thesis, Yildiz Technical University, Science Institute, Environmental Engineering, Istanbul, 2004.

5. Apaydin O., Kalender A., Gonullu M.T. (2002) Assessment of Sociological Aspect of Separate Household Solid Waste Collection in Trabzon (Turkey), ISWA 2002 World Environmental Congress and Exhibition, 8-12 July 2002, Istanbul, Turkey.

6. Kinaci C., Gorgun E., Arslan M., at. al. (2000) Private Sector Participation in Municipal Solid Waste Services-A Case Study for Kadikoy of Istanbul in Turkey, Wastecon 2000, Biennial Conference and Exhibition on Integrated Waste Management in The Millennium, 5-7 September 2000, Somerset west near Cape Town, South Africa.

7. Cointreau-Levine, S.C., (1994), Private Sector Participation in MSW Services in Developing Countries, Volume 1. The Formal Sector, The World Bank, Washington D.C., USA.

8. Taylor G.D., Whicker G.L., Usher J.S. (2001) Multi-zone dispatching in truckload trucking, Transportation research Part E, 37, 375-390.

9. Apaydin, O., (2005) A GIS Supported Optimization Application of Solid Waste Collection System in Trabzon City, Ekoloji, 54, 1-6.

10. Apaydin, O., Arslankaya, E., Avsar, Y., Gonullu, M.T., (2004) GIS supported optimization of solid waste collection: Trabzon case study, Sigma, 4, 249-254. 